\title{
FULFILLMENT OF KOCH'S POSTULATES FOR IN VITRO PATHOGENICITY OF MUSICILLIUM THEOBROMAE (TURCONI) ZARE \& W. GAMS AS THE CAUSE OF BANANA CIGAR END ROT DISEASE
}

\author{
Shirin Masudi,2*, Golam Hosein Shahidi Bonjar ${ }^{1}$ \\ ${ }^{1}$ Department of Plant Pathology, College of Agriculture, Shahid Bahonar University of Kerman, 7616914111 Iran \\ ${ }^{2}$ Young Researchers Club, Kerman Branch, Islamic Azad University, Kerman, 7619657633 Iran
}

Received: May 17, 2012

Accepted: August 20, 2012

\begin{abstract}
Pathogenicity of Musicillium theobromae (Turconi) Zare \& W. Gams (syn. Stachylidium theobromae Turconi, Verticillium theobromae E.W. Mason \& S. Hughes) causing Banana cigar end rot disease has fulfilled_Koch's Postulates for the first time. To assess and prove the pathogenicity, $M$. theobromae mycelial discs and conidia were inoculated in triplicate to surface-disinfested green banana fruits. The bananas were infected both through artificial wounds as well as through intact unwounded fruits. After inoculation, the bananas were covered with moist cotton and incubated for 30 days at $23^{\circ} \mathrm{C}$. Plain moist cotton was used on the controls. Those inoculated treatments kept under high relative humidity exhibited symptoms of banana cigar end rot disease. The controls and those kept under low relative humidity did not develop symptoms and remained healthy. The results indicated that both optimum temperature and high relative humidity are necessary for infection onset and disease development. It was also determined that infection can occur both through wounds and intact unwounded fruit epidermis. The cultural characteristics in $M$. theobromae were also investigated. It was found that the best mycelial growth occurred on potato dextrose agar (PDA) and the optimum $\mathrm{pH}$ for mycelial growth was 8.
\end{abstract}

Key words: banana, cigar end rot disease, Musicillium theobromae, pathogenicity

\section{INTRODUCTION}

Cigar end rot is an important post harvest disease of banana. It kills banana fruits while the fruits are being transported as well as while the fruits are in storage. Throughout the world, the disease reduces the market value of the fruit. Two different fungi have been reported to be associated with the disease; Musicillium theobromae (Turconi) Zare \& W. Gams and Trachysphaera fructigena (Tabor and Bunting). In west and central Africa, T. fructigena is known to cause a destructive soft rot on banana plantations (Mourichon 2003; Baker et al. 2008). Musicillium theobromae is more widespread and occurs in most banana growing regions (Meredith 1973; Boubaker et al. 2008). The major symptoms in the field consist of early pistillate necrosis which begins at the end of a pistillate. The skin folds and shrinks and there tend to be many dead floral parts. The powdery, grayish conidia form on the shriveled black end of the fruit giving rise to the appearance of "cigar end rot" from which the disease gets its name (Stover 1972; Wardlaw 1972; Stover and Simmonds 1987; Snowdon 1990; Jeger et al. 1995). The fungus is also one of the members of a pathogenic complex which cause rot to the crowns in boxed banana shipments (Slabaugh and Grove 1982; Ilyas et al. 2007). The pathogenicity of T. fructigena on banana fruits is well known, but pathogenicity of $M$. theobromae on banana fruits had not been previously proven.

Cultures of M. theobromae grow rapidly on Potato Dextrose Agar (PDA) and malt extract agar (MEA) at $23^{\circ} \mathrm{C}$. The mycelium is white, flocculose, and can be densely compacted or sparse. It becomes olivaceous grey-brown after 1-2 weeks, though never entirely black. The hyaline sectors are unknown. Conidiophores are abundant, more or less erect and have hyaline. Conidiophores sometimes become brownish below. They are verticillately branched with 3-6 phialides arising at each node. There are up to six whorls of phialides per conidiophore, and phialides are sometimes branched. Phialides are variable in size, mainly $14-37 \times 1.5-5 \mu \mathrm{m}$. Conidia arise singly at the apices of the phialides. Conidia are 3-8x1.5-3 $\mu \mathrm{m}$ and are ellipsoidal to sub-cylindrical. They have hyaline. Resting mycelium is pale brown with septate hyphae. Resting mycelium is not torulose. It is $2-3.5 \mu \mathrm{m}$ wide and often poorly developed or absent. Chlamydospores and microsclerotia are absent (Gams 2007). In the Plectosphaerellaceae family, M. theobromae is the only known teleomorph taxon (Zare et al. 2007).

In this study, we were the first to fulfill Koch's postulates for the pathogenicity of $M$. theobromae (Turconi) Zare $\&$ W. Gams in which the pathogen caused Banana cigar end rot disease. 


\section{MATERIALS AND METHODS}

\section{Preparation of the pathogen}

Pure culture of $M$. theobromae with the accession number: Q5BM88, was obtained from the fungal collection of the Iran Plant Protection Research Institution, Tehran, Iran. Subcultures of the pathogen were prepared on PDA medium (Merk) and kept refrigerated for further studies.

\section{Preparation of banana fruits}

Green bananas of the Dwarf Cavendish variety were obtained from a banana tree in the greenhouse of the College of Agriculture in Shahid Bahonar University, Kerman, Iran.

\section{Surface disinfection of banana fruits}

Prior to the treatments, the young banana fingers were surface disinfested in three stages. First, the banana fingers were washed with water, rinsed and air dried. Next, they were surface disinfected using ethanol 75\% and rinsed. Then, the fingers were submerged for $2 \mathrm{~min}$ utes in a $10 \%$ Clorox solution and rinsed with sterilized distilled water. Surface disinfested fruits were air dried under a laminar hood and used in pathogenicity trials.

\section{Inoculation treatments}

This test was performed with six treatments in which surface sterilized green intact banana fingers were used. Each treatment was replicated three times. Fungal disks were prepared from margin of fresh lawn culture of M. theobromae on PDA medium by using. A a sterilized cork borer with a diameter of $6 \mathrm{~mm}$.. All treatments were incubated for 30 days at $23^{\circ} \mathrm{C}$ which is the optimum temperature for growth of the pathogen.

\section{Treatments}

Set 1a) Scalpel/needle wounding plus moist cotton pads

On distal ends and lateral middle-part surfaces of fingers, two wounds were created by either an scalpel (2-3x1-2 mm) or needle (1 mm in depth). One fungal agar disk was placed on each wound. The inoculated fruits were covered with a sterile moist cotton pad, wrapped with parafilm, put in sterilized capped plastic containers and incubated as described. As controls, a similar set of fingers were treated similarly with; plain agar plugs.

\section{Set 1b) Scalpel/needle wounding without moist cotton pads}

On distal ends and lateral middle-part surfaces of fingers, two scalpel wounds of $2-3 \times 1-2 \mathrm{~mm}$ or needle wounds of $1 \mathrm{~mm}$ in depth were created. One fungal agar disk was placed on each wound but uncovered and put in sterilized capped plastic containers and incubated as described. As controls, a similar set of fingers were treated similarly; plain agar plugs were used.

\section{Set 2a) Needle wounding plus high relative humidity}

On distal ends and lateral middle-part surfaces of fingers, two needle wounds of $1 \mathrm{~mm}$ in depth were created. One fungal agar disk was placed on each wound and put placed in sterilized capped Pyrex dishes containing $10 \mathrm{ml}$ of sterile distilled water. The water was meant to provide high relative humidity throughout the experiment. Incubation took place as described. To prevent direct contact of fingers with water, sterilized glass Petri plates were placed on each dish bottom and the treated fingers were placed on the plates. As controls, a similar set of fingers were treated similarly; plain agar plugs were used.

\section{Set 2b) Needle wounding without high relative humidity}

On distal ends and lateral middle-part surfaces of fingers, two needle wounds of $1 \mathrm{~mm}$ in depth were created. One fungal agar disk was placed on each fruit wound. Treated fruits were put in sterilized capped dry Pyrex dishes and incubated as described. As controls, a similar set of fingers were treated similarly; plain agar plugs were used.

\section{Set 3a) No wound inoculation but high relative humidity}

From a PDA well grown culture, spores of the pathogen were rubbed on distal ends of the fingers. Sterilized cotton swabs were used to do the rubbing. The inoculated fruits were placed in sterilized capped Pyrex dishes containing $10 \mathrm{ml}$ of sterile distilled water. The water was meant to provide high relative humidity throughout the experiment. Incubation took place as described. To prevent the banana fingers from having direct contact with water, the banana fingers were placed on sterilized glass Petri plates. The plates were placed on the dish bottoms. As controls, a similar set of fingers were treated similarly; plain cotton swabs were used.

\section{Set 3b) No wound inoculation, no high relative humidity}

From a PDA well grown culture, spores of the pathogen were rubbed on distal ends of the fingers. Sterilized cotton swabs were used to do the rubbing. The inoculated fruits were placed in sterilized dry capped Pyrex dishes and incubated as described. As controls, a similar set of fingers were treated similarly; plain cotton swabs were used.

\section{Microscopic studies and fulfillment of Koch's postulates}

After the appearance of disease symptoms in the inoculated fruits, the pathogen was reisolated on PDA from artificially diseased fruits. Under light microscope, morphological criteria of the reisolated fungus compared and matched with the originally inoculated ones.

\section{Cultural characteristics}

Optimal mycelia growth was determined on different culture media. The media used included: PDA, MEA, NA (nutrient agar), SDA (sabouraud dextrose agar) and CMA (corn meal agar). The optimum $\mathrm{pH}$ for mycelial growth was investigated by using PDA media. Their $\mathrm{pH}$ was adjusted from 5.0 to 10.0 by increments of one (Lim et al. 2002). Cultural characteristics of the fungus were evaluated from the growth performance on culture plates. A 14day incubation at $23^{\circ} \mathrm{C}$ was followed by the evaluation. 


\section{RESULTS}

\section{Inoculation treatments}

The onset of disease and the progression of symptoms were observed in the treatment sets of $1 \mathrm{a}, 2 \mathrm{a}$ and $3 a$. Treatment sets of $1 b, 2 b$ and $3 b$ and all the controls, on the other hand, remained symptomless and did not show signs of the disease. Symptoms of the diseased fruits consisted of: tissue necrosis in the vicinity of the inoculated sites on finger peels, and appearance of fungal tissue with white-gray colored conidial masses at fruit distal ends which developed to typical cigar end rots. Figure 1 shows the onset and progression of laboratory-induced Banana cigar end rot disease symptoms which resulted from artificial inoculation with $M$. theobromae on banana fruits. Incubation had taken place at $23^{\circ} \mathrm{C}$ for 30 days. Details included in figure 1 are: A) Tip necrosis symptoms on the finger tip from the treatment in which needle wounding and moist cotton pads were used, B) Sunken peel necrosis symptoms on the lateral finger portion from the treatment in which needle wounding and moist cotton pads inoculated with mycelial agar plugs were used, C) Sunken peel necrosis on finger lateral portion from the treatment in which scalpel-wounding and moist cotton pads inoculated with mycelial agar plugs were used, D) End and lateral necrosis symptoms at distal and lateral portions of finger fruits from the treatment in which needle wounding and high relative humidity were used, E) Tip and end necrosis symptoms from the treatment where no wound was made but inoculation with conidia using a cotton swab was done. High relative humidity was used in this treatment.
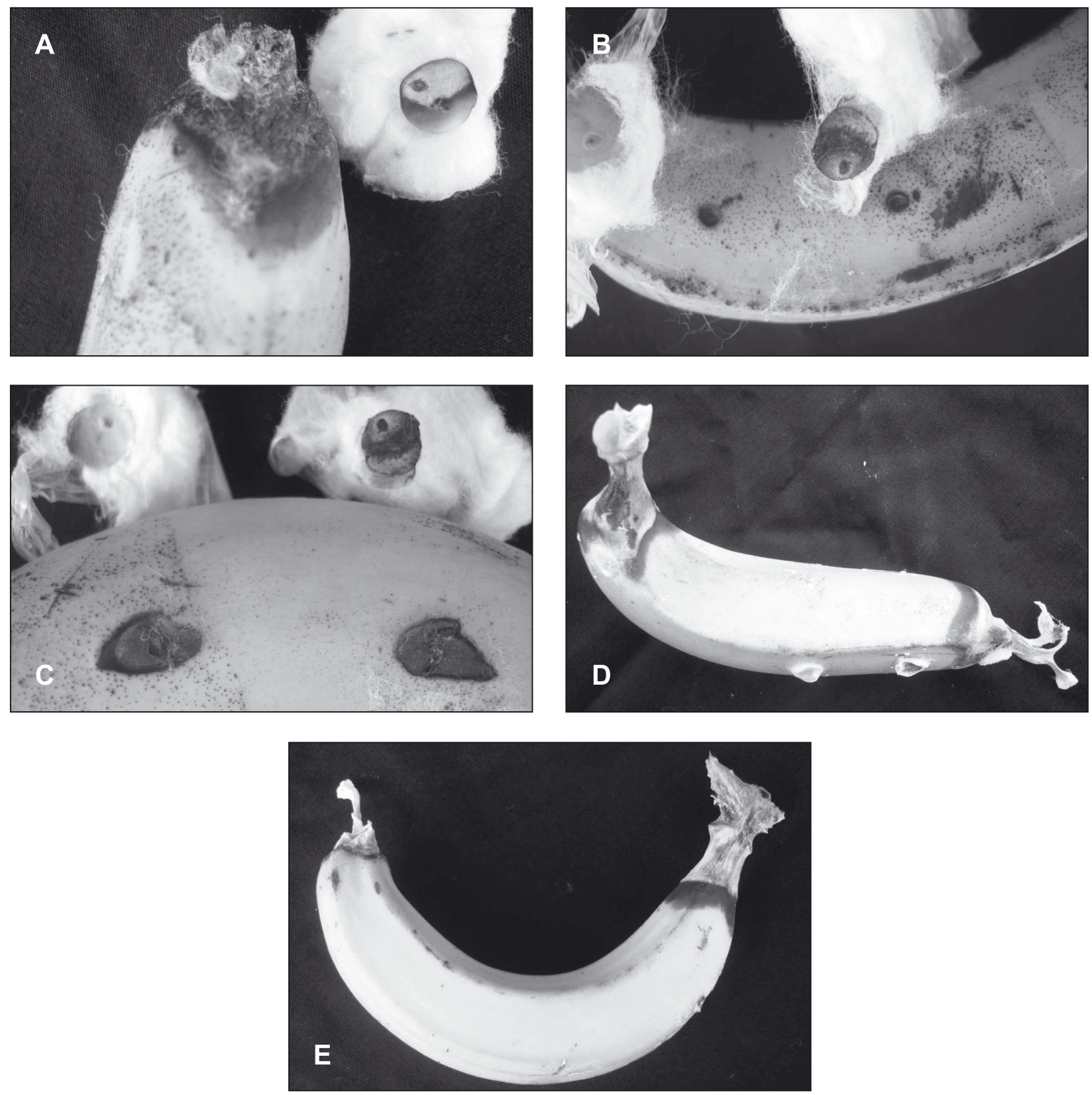

Fig. 1. Onset and progression of laboratory-induced Banana cigar end rot disease symptoms, which resulted from artificial inoculation with $M$. theobromae on banana fruits, took place after a 30-day incubation period at $23^{\circ} \mathrm{C}$. Details are described in the text 
Microscopic studies and fulfillment of Koch's postulates

Morphological characteristics of the mycelia, conidiophores, phialids and conidia of the isolated fungus (Fig. 2)

matched the features of the originally inoculated M. theobromae. The results indicated that Koch's postulates had been clearly fulfilled.

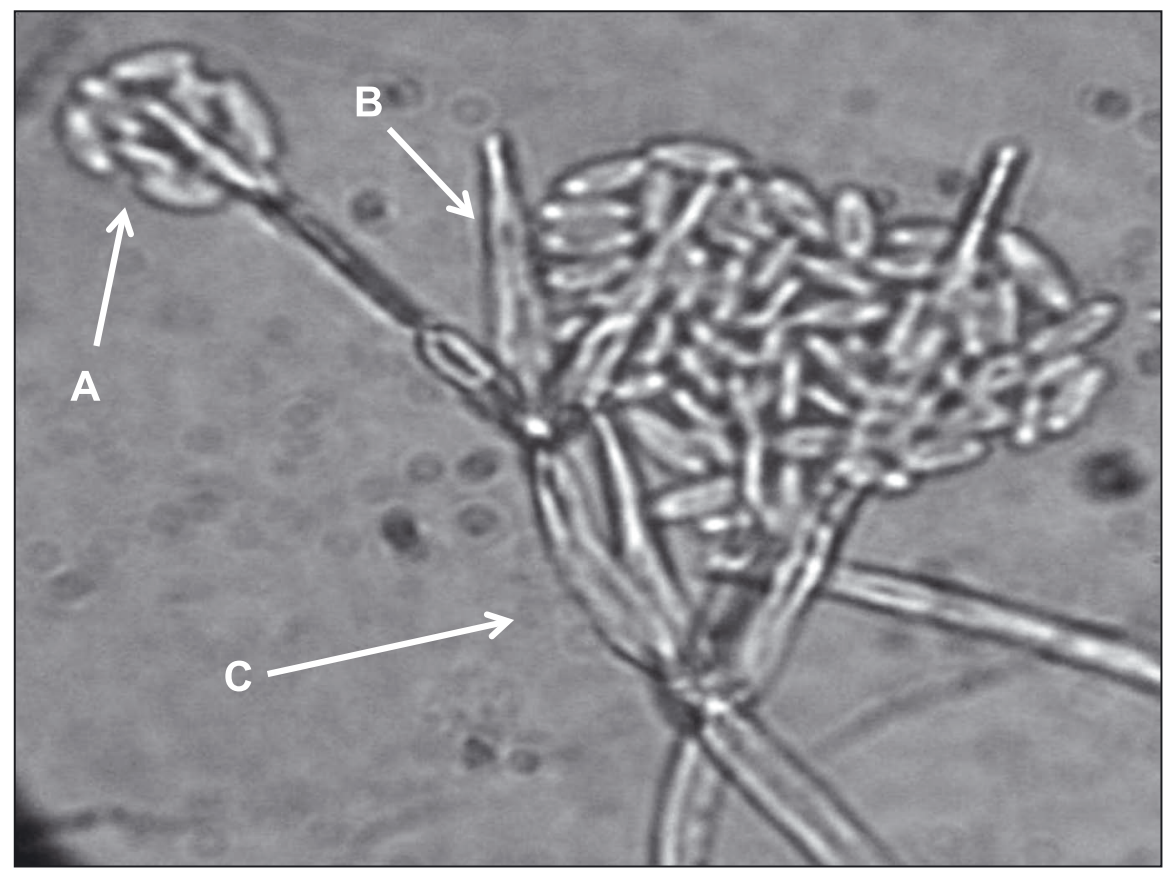

Fig. 2. Morphological features of $M$. theobromae under light microscope at $40 \mathrm{X}, \mathrm{A}$ ) Conidia, B) Phialide, C) Conidiophor

\section{Cultural characteristics}

Among the five evaluated culture media, PDA was most suitable for mycelial growth of the pathogen on which the colony diameter of $M$. theobromae reached $70 \mathrm{~mm}$ after 14 days at $23^{\circ} \mathrm{C}$. Under similar growth conditions, CMA was the least suitable medium (Fig. 3). The optimum $\mathrm{pH}$ for mycelial growth was a $\mathrm{pH}$ of 8.0, while minimum mycelial growth occurred at a $\mathrm{pH}$ of 5.0 (Fig. 4).

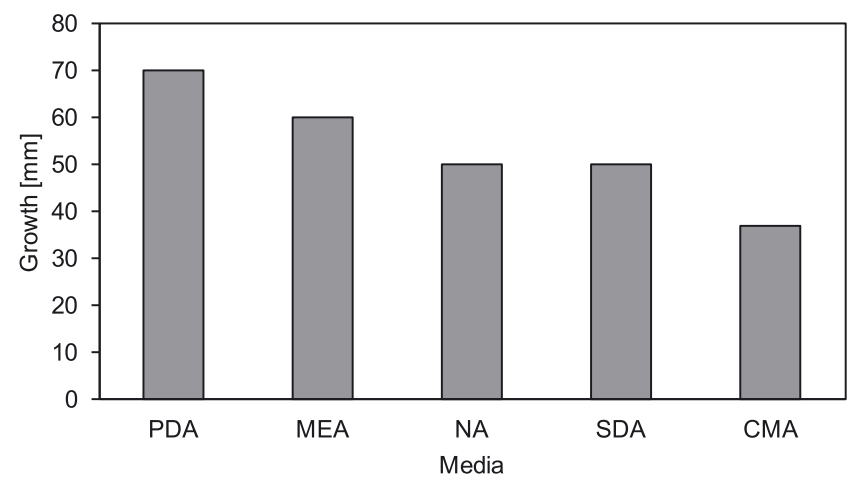

PDA - Potato Dextrose Agar MEA - malt extract agar $\mathrm{Na}$ - nutrient agar SDA - sabouraud dextrose agar CMA - corn meal agar

Fig. 3. Comparative growth of $M$. theobromae mycelia on various media, under a 5-day incubation period at $23^{\circ} \mathrm{C}$

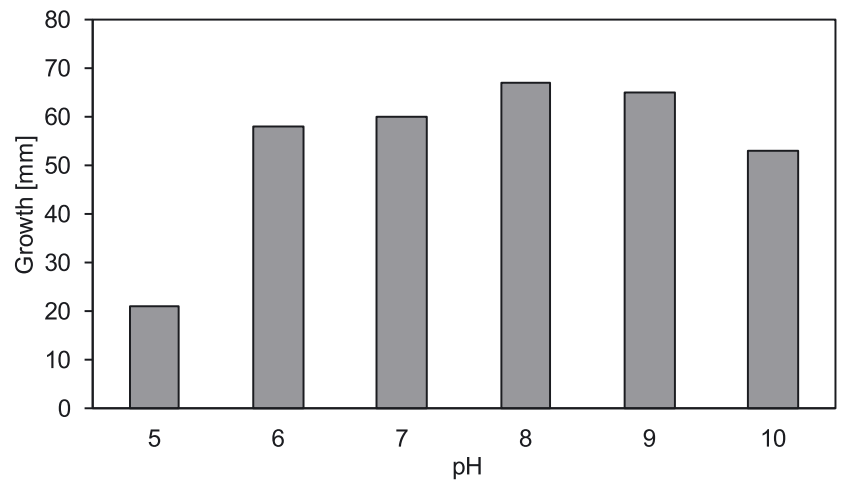

Fig. 4. Comparative growth of $M$. theobromae mycelia on PDA medium at different $\mathrm{pH}$ intervals, after a 14-day incubation period at $23^{\circ} \mathrm{C}$ 


\section{DISCUSSION}

Pathogenicity of $M$. theobromae as the causal agent in banana cigar end rot disease was proved and Koch's postulates were fulfilled in this study. Previous investigators, such as Wardlaw (1931), Meredith (1965) and Ershad (1972), could not regenerate the disease artificially. Wardlaw (1931) was the first person who probed into the disorder. He was unable to prove the pathogenicity, but he said that $M$. theobromae is involved in the malady of the banana cigar end rot disease. Ershad (1972) believed there was a relation between fruit physiology and the cause of the disease. He said that according to Meredith's theory (1965), fruits have to be in a particular condition before successful infection can takes place. He pointed out that the causal agent of the disease is a weak pathogen. He said that probably before an attack, the fungus $M$. theobromae, infection of other fungal pathogens, or presence of a wound are necessary for the onset of infection. Ershad (1972) agreed with Meredith's theory but stated that presence of a wound by itself is not enough for infection onset. He noticed that fruit extract inhibits the germination of conidia and slows down mycelial proliferation.

In the present investigation we succeed in finding out that pathogen $M$. theobromae causes banana Cigar end rot disease.

According to the results observed, we conclude that the combination of proper temperature $\left(23^{\circ} \mathrm{C}\right)$ and saturated relative humidity are factors leading to the onset of infection and the progression of the disease. Our results also indicated that a wound is not necessarily the route for infection since infection leading to typical symptoms also occurred through fruit peels which had not been wounded.

Meredith's opinion was that the causal agent of disease is a slow-growing, weak pathogen. We noticed that the pathogen is slow-growing but it is not weak; because it did cause the disease when appropriate infection conditions were provided. We would also like to point out that the reason behind the high incidence of post harvest disease in banana fruits is that banana finger-bunches are packed in plastic bags (generally $2-4$ in each paper shipping-box) for storage and shipping. The relative humidity inside these plastic bags reaches the saturation point soon after packaging. Such conditions favor infection by the spores of the pathogen. The spores are present as surface contaminants originating from the field. Changing the packaging method would prevent the high relative humidity inside storage and packaging containers. Such changes would diminish the post harvest losses caused by the disease, during storage, shipping, and transportation to markets.

\section{ACKNOWLEDGEMENTS}

This research is part of the thesis project for a MSc degree in Plant Pathology at the Department of Plant Pathology, College of Agriculture, Shahid Bahonar University. We wish to thank the Head of the Research Affairs Office of Bahonar University of Kerman for the financial support for the project. Dr. Zare from the Iran Plant Protection Research Institution, Tehran, Iranwhich kindly provided the pure $M$. theobromae culture as well as much helpful information. This research is dedicated to Mr. A. Afzalipour, the founder of Bahonar University in Kerman, Iran.

\section{REFERENCES}

Baker R., Caffier D., William Choiseul J., De Clercq P., Dormannsne S., Barbel G. Karadjova O.E, Lövei G., Lansink A.O., Makowski D., Manceau C., Manici L., Perdikis D., Puglia A.P., Schans J., Schrader J., Steffek R., Strömberg A., Tiilikkala k., .K.V., Vloutoglou I. 2008. Pest risk assessment made by France on Trachysphaera fructigena considered by France as harmful in French overseas departments of French Guiana, Guadeloupe, Martinique and Reunion1. Scientific Opinion of the Panel on Plant Health. Eur. Food Safe. J. 664 (1): 1-23.

Boubaker H., Saadi B., Boudyach E.H., Ait Benaoumar A. 2008. Resistance of Verticillium theobromae to benzimidazole fungicides in Marocco. J. App. Sci. 8 (21): 3903-3909.

Ershad J. 1972. Occurance of cigar-end disease of banana in Iran. Iran. J. Plant Pathol. 8 (1): 10-16.

Gams W. 2007. Fungal Databases-Numenclture and Spicies banks- Online Taxonomic Noveltise submission, Musicillium theobromae. http://www.mycobank.org/MycoTaxo. aspx?Link=T\&Rec=307743. Accessed: April 26, 2011.

Ilyas M.B., Ghazanfar M.U., Khan M.A., Khan C.A., Bhatti M.A.R. 2007. Post harvest losses in apple and banana during transport and storage. Pak. J. Agri. Sci. Vol. 44 (3): 534-539.

Jeger M.J., Eden-Green S., Thresh J.M., Johanson A., Waller J.M., Brown A.E. 1995. Banana diseases. p. 317-381. In: “Bananas and Plantains" (S. Gowen, ed.). Chapman and Hall, London, 545 pp.

Lim J., Lim T.H., Cha B. 2002. Isolation and identification of colletotrichum musae from imported bananas. Plant Pathol. J. 18 (3): 161-164.

Meredith D.S. 1960. Deightoniella torulosa (Syd.) Ellis and Verticillium theobromae (Turc.) Mason \& Hughes associated with a tip-rot of banana fruits. Brit. Mycol. Trans. J. 44 (4): 487-492.

Meredith D.S. 1963. Tip rot of banana fruits in Jamaica. I. Hendersonula toruloidea on Dwarf Cavendish bananas. Brit. Mycol. Trans. J. 46 (4): 473-481.

Meredith D.S. 1965. Tip rot of banana fruits in Jamaica: II. Verticillium theobromae and Fusarium spp. Brit. Mycol. Trans. J. 48 (2): 327-336.

Meredith D.S. 1973. Epidemiplogy consideration of plant diseases in the tropical enviroment. Phytopathology 63 (6): 1446-1454.

Mourichon X. 2003. Trachysphaera fructigena Responsible for the disease "cigar butt" banana. http://agriculture.gouv.fr/ IMG/pdf/BAN-c5.pdf. Accessed: April 26, 2011.

Slabaugh W.R., Grove M.D. 1982. Post harvest diseases of banana and their control. Plant Dis. 66 (8): 746-775.

Stover R.H. 1972. Banana, plantain, and abaca diseases. Comm. Agric. Bur., Slough, UK, 316 pp.

Stover R.H., Simmonds N.W. 1987. Bananas. Longman Scientific and Technical, Essex, UK, 468 pp.

Wardlaw C.W. 1931. Banana diseases 2: Notes on cigar-end (Stachylidium theobrome Turc). Trop. Agric. 8 (2): 293-298.

Wardlaw C.W. 1972. Banana Diseases Including Plantain and Abaca. 2nd ed. Longman, London, UK, 878 pp.

Zare R., Gams W., Starink-Willemse M., Summerbell R.C. 2007. Gibellulopsis, a suitable genus for Verticillium nigrescens, and $M u s i c i l l i u m$, a new genus for $V$. theobromae. Nova Hedwigia 85 (3-4): 463-489. 